\title{
Tourism In Developing Countries. The Path Towards Sustainable Development And Its Interaction With The Local Communities, The Environment And The Human Factor
}

\author{
https://doi.org/10.21272/sec.4(2).80-86.2018
}

\section{Andreas Karaoulanis}

MScEng, Aristotle University, Greece; MBA, Blekinge Institute of Technology; Masters in Decision Support and Risk Analysis, Stockholm University; Masters in Information Systems, Linnaeus University, Sweden

\section{Koukousouri Vasiliki}

Bachelor of Philosophy, University of Ioannina; Masters in Behavioural Sciences, Greek Open University, Greece

\begin{abstract}
This paper summarizes the arguments and counterarguments within the scientific discussion on the issue of tourism in developing countries. The main purpose of this literary analysis is to underline the importance and to shed some light on how government's policies, environmental issues, corporate social responsibility and growth strategies impact in tourism development in developing countries. Also, the paper tries to explain in which way tourism development in such countries impacts in their poor local population.
\end{abstract}

Systematization literary resources and approaches for solving the problem of poverty alleviation in developing countries via the tourism development indicate that although according to some researchers tourism development can be a powerful tool in poverty alleviation, there are other researchers who tend to believe that the phenomenon has an opposite direction. Social development leads to tourism development.

After investigation of the topic, the authors of the paper concluded that tourism development need the local authorities' assistant in order to be able to alleviate poverty. Rules needed to be implemented, otherwise in cases like the medical tourism etc. the results could be stressful as they can lead to an increase of the wealth of specific only social groups, leaving the real poor ones outside.

The topics investigation was carried out in the following logical sequence: Firstly, the authors underlined some important points about tourism in general and especially in developing countries. They continued with a reference to environmental paragons involved. They stressed the notion of "tourism for the poor" and continued with the role of the local authorities only to end up with a debate of whether tourism development lead to social growth or vise-versa?

The results of this literary analysis indicate that further investigation is needed in order to understand clearly the answer to the above mentioned debate. This answer is crucial as it will lead us towards the right direction by let us understand if we need to start from the within (growth of the local society which will lead to tourism development), or the other way around.

This paper can be the springboard for the researcher of the future towards the deeper understanding of the problem in question. The paper has as its main target to show a path way towards poverty alleviation in developing countries by the use of tourism as the vehicle which will carry it out.

Keywords: tourism, poverty, environment, corporate social responsibility, governmental policies, weather, local societies.

\section{JEL Classification: Z32.}

Cite as: Andreas Karaoulanis, A., Vasiliki, K. (2018). Tourism In Developing Countries. The Path Towards Sustainable Development And Its Interaction With The Local Communities, The Environment And The Human Factor. SocioEconomic Challenges, 4(2), 80-86. https://doi.org/10.21272/sec.4(2).80-86.2018.

(C) The Authors, 2018. This article is published with open access at Sumy State University. 


\section{Introduction}

A very interesting debate nowadays is whether tourism can be a powerful tool for poverty alleviation in developing countries. Many researchers argue in both directions, stressing that tourism can be the means for poverty alleviation but cannot be also as it has to do with many paragons involved in the whole procedure.

According to Ghimire (2001), regional tourism within developing countries is a growing phenomenon. The importance of this phenomenon is obvious, but there are many things to be discussed in terms of whether tourism money reach poor people in such countries.

\section{Tourism and developing countries}

Tourism nowadays and especially since 1950 (after World War II), has presented globally a very strong growth. That resulted in making the tourism industry very powerful and one of the more important in the world (Almeida-García, 2018). According to the same author, many governments in order to support such development, have implemented specific policies which aimed at generating income from tourism for their countries (Almeida-García, 2018). This was the case for many developing countries as well, but not for all of them.

It is the author's prevalent idea that developing countries didn't understand or didn't have the time to understand the importance of centralized policies' implementation towards tourism growth in their countries, mainly due to the fact that they had to deal with numerous other equally and even more important issues (i.e. overcoming wars, struggling for independence, developing main infrastructures etc.).

In order to be able to sustain its tourism development, developing countries need to implement specific strategies towards that goal. According to Sanaul Haque Mondal (2017), who investigated the paradigm of Bangladesh, in order the local authorities to be able to develop a sustainable tourism industry in the country, need to address WT (Weaknesses-Threats) policies/ strategies such as ensuring safety and security for tourists, effective planning for sustainable economic benefits, strict implementation of environmental regulations for ecological sustainability, alerting people about the importance of sustainable tourism development, and infrastructure development.

Such policies in such an important touristic destination country will be able to help the country of Bangladesh to overcome the challenges the specific industry is facing and to move towards sustainable development (Sanaul Haque Mondal, 2017).

According to Mahato (2013), in recent years the industrialization temptation in combination with the growing population has caused significant problems to the tourism industry. The efforts made by the local governments are proved to be not adequate enough to ensure the industry's sustainability.

\section{Tourism and environment in developing countries}

Sustainable tourism has become lately a very important topic due to the fact that in many occasions tourism can be over exploitive of resources and can be tend to degrade them something which can be disastrous, especially for the developing world (Badulescu et al., 2015).

Coastal tourism and tourism in general is a very important factor in terms of developing countries' economic growth. In spite of its importance, the local governments of many developing countries has often developed tourism infrastructure without taking into full consideration of their long- term impact to the environment (Anctil and Blanc, 2016). The governments' role regarding encouragement to entrepreneurs in terms of using cleaner technologies in the tourism sector and to present different approaches for sustainability thru their implemented policies, is extremely crucial according to Yfantidou and Matarazzo (2017).

For example, Whitelaw et al. (2014) stress that the traditional reliance on government sources in terms of supporting protected areas is increasingly untenable in both the developed and the developing countries. Such statements are clearly showing how important is the governments' intervention in terms of how the developing countries would be able to attain sustainable touristic development without engage in devastating the local eco- system.

Another important aspect in terms of the correlation between environment and touristic development in developing countries is the voluntary environmental programs (Rivera, 2002). According to Rivera (2002), such environmental initiatives can be effective environmental policy instruments for the local governments. 
Finally, another important form of tourism is the "research ecotourism" which according to Clifton and Benson (2006) is a relatively new component of activities within the eco-tourism industry and is providing research opportunities for tourists that visiting developing countries. Clifton and Benson (2006) stress that such activities can have several socio-cultural impacts to local societies.

It is important here to underline that the environmental paragon is extremely important in developing destination countries because it has enormous economic impact.

The improvident changing of natural environments can lead to natural disasters, especially in countries which facing extreme climate phenomena throughout the year, like typhoons, extreme periods of heavy raining etc.

According to a Schmude et al. (2018) research which took place in the island of Dominica, a micro- level assessment model was developed in order to calculate the precise damage assessments and to be able to analyze and understand the impact at the micro-level supporting tourism recovery in an affected destination.

The research showed that there are a lot of consequences for the local communities. The authors also highlighted the importance of damage assessments on a small-scale level such as local communities in order to distinguish the individual regions facing severe changes for resident livelihoods from the local tourism sector.

The paramount importance of this research is underlined by the authors' argument that "only after identifying regional impacts it is possible to apply adequate governmental subsidies and development strategies for a country's tourism sector and residents in a continuously changing environment in the hopes of mitigating future financial losses and future climate change impacts” (Schmude et al., 2018).

Such researches highlight the fact that in order to implement a national tourism strategy which will have a positive impact to the community on local and national level, it is extremely important that the implemented policies will be based on scientific data which accordingly will formulate the appropriate tool (models) which will describe the needs of the communities in a more solid way. The climate paragon and the way that we exploit environment are two paragons that need to be taken extremely seriously in order not to convert positive to negative results which will affect the country's financial, tourism and eco stability and growth.

\section{Tourism for the poor?}

Tourism industry in developing countries rely in many cases upon the investment of foreign companies. There is a debate at the outskirts of corporate social responsibility about whether such investors have to take under strong consideration the implications of their expansion policies to the local population.

Companies nowadays are under intense pressure to rebuild public trust in parallel with their efforts to stay competitive (Jamali, 2007). Although successful companies worldwide develop specific strategies for doing business in emerging markets, strategies that take into account i.e. the local institutional voids (Khanna et al, 2005), it is argued that especially when it comes to tourism, such strategies should be about planning and implementing for the local residents as well as for visitors too (Liu and Wall, 2006).

Liu and Wall (2006), argue also that if tourism is going to be a positive force that will shape positively the lives of the indigenous population, it should be contingent upon the local response, involvement and support. She continues that as many tourism development plans give no or little attention to the local human resources, such attitude should be changed and tourism companies that invest in developing countries need to focus more on human resources not only in terms of employment offers which usually cover the large international companies' needs for personnel, but to expand to the personnel's needs under a broader spectrum (Liu and Wall, 2006).

According to Hal (2007), "pro-poor" 1 tourism (PPT) is currently receiving enormous attention from the World Tourism Organization (WTO), the United Nations (UN) SYSTEM, governments, industry and Non- Governmental Organizations (NGOs) and, especially in developing countries, it is an integral component of many sustainable development strategies.

Harrison (2008) stresses that tourism's role as a development tool has increased, especially the last thirty years, while its contribution to poverty alleviation was and still is a bit blur picture and the basis of many debates. At the end of 1990s the emergence of "pro- poor" tourism has brought the issue to the surface more dynamically this time (Harrison, 2008).

\footnotetext{
${ }^{1}$ Tourism that is intended to result in increased net benefits for poor people (Hal, 2007).
} 
In his paper about PPT, Gascon (2015) argues that the PPT concept of poverty circumvents the fact that an unequal distribution of income in terms of poor and non- poor people in the local community, could imply a loss in the quality of life for the majority of the rural local population. This can be very helpful for the highincome social sector who under such circumstances tend to increase its economic and political power to the detriment of other social sectors (Gascon, 2015).

\section{The bigger picture}

Tourism is not an industry which is operating apart from the other ones on a different planet. As part of the global economy it has to follow specific rules and trends which are developed due to the globalization and all its consequences to the global markets.

According to Dollar (2005), there are five trends in the modern era of globalization which integrate inequality and poverty. These trends are the following:

1. Growth rates in poor economies have accelerated and are higher than growth rates in rich countries for the first time in modern history.

2. The number of extremely poor people in the world has declined significantly.

3. Global inequality has declined modestly, reversing a 200-year trend toward higher inequality.

4. Within-country inequality in general is not growing, though it has risen in several populous countries (China, India, the United States).

5. Wage inequality is rising worldwide (Dollar, 2005).

The above mentioned trends have many implications in the tourism industry as well and especially in the developing countries. The fifth trend for example underlines why in many cases people from western countries where the income is higher, tend to visit developing countries etc.

Of course in the tourism in developing countries case, specific other factors are playing an equally vital role in terms of the local country's development. For example, in developing countries of tourist destinations, an increase in medical tourism can unleash a raise in the medical sector's wages in the local community, something that although seems to be a positive development for the locals can also have negative results such as the loss of revenue and labor productivity (Beladi et al, 2015).

\section{The govermental intervention}

An important factor that needed to be investigated here is the governmental paragon in the deployment and implementation of a touristic project in a developing country.

According to Elnasr Sobaih et al. (2015) research which took place in Egypt, the impact of the tourism and hospitality industry in the economy and the social development of the country in question is huge. The problem was and still is that the policy makers do not pay the attention needed in such industries, in terms of education and research. While talking of policy makers, the authors mainly underline the importance of the local government.

It is important here to understand that governments of developing countries can play a vital role in developing their economic growth via the expansion of their tourism industry.

Under this prism, it is extremely important that Universities of such touristic destination countries need to implement tourism- centric education. Funds need to be invested in research via Universities on issues connected to the local tourism in order to help the government, in collaboration with all the involved stakeholders, to implement the right policies and the strategies in order to achieve the growth of the tourism industry in the country in question.

According to a research that was implemented by Dwyer et al. (2012) in Cambodia although tourism goes some way in reducing poverty in Cambodia, its impact could have been further increased by informed policy initiatives.

The authors of the above mentioned research paper stress that a very important barrier that needed to be eradicated in terms of the formulation of the appropriate policies that needed to be implemented in Cambodia 
towards the increase of the Pro- Poor benefits is the limited data available. They also argue that this phenomenon is something that we are facing in poor countries generally.

It is obvious from the above mentioned research, that poor countries are facing a lack of research on tourism, something which is the result of under- developed universities. The Universities' funding need to be one of the most important parts of the country's annual budget as education and research will be the cornerstone of the country's tourism development and sustainable growth.

Governmental executives need to understand that the tourism industry in their countries need to be built upon solid foundations which will be of course a collaborative between stakeholders spirit, the ideas exchange and most of all, the growth of academic knowledge and research on the topic.

\section{Tourism development towards economic growth or vise versa?}

A quite interesting approach on the nexus between tourism, the human development and economic growth is the result of a research contacted by Rivera (2017) in Equador, a developing country of the American continent.

According to that research there were three important results. Firstly, it is amazing that "tourism does not promote human development" (Rivera, 2017). Instead, the author argues that is the degree of the human development that promotes tourism and not vise-versa. Secondly, economic growth and human development are tightly connected via a virtuous circle and thirdly, that tourism growth is a product of economic growth and not vise- versa.

Although the bond between economic growth and human development is obvious all around us, there are several disputes in terms of whether or not tourism growth can promote human development and of course whether tourism growth is the result of economic growth and not the opposite around.

Such approaches are indicative of the various points of view on the subject. It is important to understand that the model implemented in the Equador case by the author is not a representative one in terms of covering all the aspects that we can encounter in all developing countries. It is also not in the author's of this paper intentions to investigate the correctness of the specific research. What is important though and food for thinking is the third result that "tourism growth is a product of economic growth and not vise- versa".

According to a research conducted Du et al. (2016), which developed a tourism growth model that is extension of Solow (cited in Du et al. 2016) and estimated their model with a cross- section of 109 countries worldwide, the investments in tourism appeared to be insufficient for the country's economic growth. Instead the tourism's contribution to the long- term growth of an economy in question, comes through its role as an integral part of the company's broader implemented strategy which is generally focused on standard income determinants.

In more plain words, the researchers argue that tourism itself is not a strong determinant of the country's economic growth and prosperity, something which is in accordance, at least partially, with the Equador research conducted by Rivera.

If such researches are indicative of the reality in the global economy and especially in developing countries, then maybe we need to re consider whether the development of tourism in developing countries can be the springboard for a potential future economic growth thus the poverty alleviation of the local societies. Of course the issue is extremely complicated and cannot be addressed properly and in a cohesive way here.

On the antipode of course, in the book of Christie et al. (2014) "Tourism in Africa:Harnessing Tourism for Growth and Improved Livelihoods “, we can that the authors argue that tourism can be the economic energizer for developing countries such as the ones in Africa, as its benefits seems quite clear as it can trigger infrastructure improvements, create new and "good" jobs, increase domestic consumption, diversify exports. The authors also argue that it empowers women, young people and marginalized population and stimulates cultural heritage and environmental conservation.

In the research conducted by Schubert et al (2011), which applied an econometric methodology to annual data of Antigua and Barbuda from 1970 to 2008, the used model showed that an increase in the tourism demand leads to transitional dynamics which gradually increasing economic growth and increasing trading. The researchers implemented a co- integration analysis which revealed that there is an existence of a long- run relationship between variables of economic growth, international tourism earnings and the real exchange rate (Schubert et al., 2014). 
We can continue that way stressing the differentiation in findings between researches on the topic. The important thing is that tourism growth and economic development are going hand by hand and there are several ways that we can use in real life that can boost economic growth via tourism development and vise- versa. Paragons that we need to have in mind while analyzing such correlations are the social impact, the local microeconomies, possible economies of scale that might exist in the area, the weather, the environment and the impact it might has in terms of physical disasters which can be prevented if we can implement policies that are very cautious in terms of human interaction with the local environment, the research background needed, the knowledge needed to be acquired via the development of the academic level in the country in question and last, but not least, the governmental paragon via the policies and the overall strategy needed for such purpose.

\section{Conclusions}

Nowadays, poverty alleviation is a very important issue for the globalized world. Developing countries in order to alleviate their poverty problems seek new forms of growth and sustainable development. Tourism industry can be the vehicle towards such direction but needs to have assistance from all the paragons involved, namely the local government, the local society, the tourists (domestic and foreign) and the big corporations who invest in such countries.

Specific governmental policies need to be implemented towards that direction and environmental issues need to be taken into account in order to create the right frame which will help the industry to expand and grow based upon solid foundations.

The growth of the tourism education on University level and the development of the appropriate data bases in terms of financial, ecological, societal and tourism issues in order to be used on research projects regarding the deployment of the right tourism sector strategies that the governments in question need to implement, are some of the most important paragons involved in developing countries' tourism industry.

Finally, whether tourism development can lead to economic growth or vise-versa or both is a debate that need future research in order to be addressed properly. Such debate is extremely important, especially in developing countries which seek economic growth via their tourism industry.

\section{References}

1. Almeida-García, F. (2018). Analysis of tourism policy in a developing country: the case of Morocco. Journal of Policy Research in Tourism, Leisure and Events, 10(1), 48.

2. Anctil, A. \& Blanc, D.L. (2016). An educational simulation tool for integrated coastal tourism development in developing countries. Journal of Sustainable Tourism, 24(5), 783-798.

3. Badulescu, D., Badulescu, A. \& Bac, D. (2015). Tourism and poverty in developing countries. The case of India and Romania. Revista de Turism: Studii si Cercetari in Turism, 20, 27-33.

4. Beladi, H., Chao, C., Ee, M.S. \& Hollas, D. (2015). Medical tourism and health worker migration in developing countries. Economic Modelling, 46, 391-396.

5. Christie, I., Fernandes, E., Messerli, H. \& Twining-Ward, L. (2014). Tourism in Africa: Harnessing Tourism for Growth and Improved Livelihoods, World Bank Publications, US.

6. Clifton, J. \& Benson, A. (2006). Planning for Sustainable Ecotourism: The Case for Research Ecotourism in Developing Country Destinations. Journal of Sustainable Tourism, 14(3), 238-254.

7. Dollar, D. (2005). Globalization, Poverty, and Inequality since 1980. The World Bank Research Observer, 20(2), 145-175.

8. Du, D., Lew, A.A. \& Ng, P.T. (2016). Tourism and Economic Growth. Journal of Travel Research, 55(4), 454-464.

9. Dwyer, L. \& Thomas, F. (2012). Tourism yield measures for Cambodia. Current Issues in Tourism, 15(4), 303-328.

10. Elnasr Sobaih, A. \& Jones, E. (2015). Bridging the hospitality and tourism university-industry research gap in developing countries: The case of Egypt. Tourism and Hospitality Research, 15(3), 161-177.

11. Gascón, J. (2015). Pro-Poor Tourism as a Strategy to Fight Rural Poverty: A Critique. Journal of Agrarian Change, 15(4), 499-518.

12. Ghimire, K.B. (2001). Regional Tourism and South-South Economic Cooperation. The Geographical Journal, 167(2), 99-110.

13. Hall, C.M. (2007). Pro-poor Tourism: Who Benefits?: Perspectives on Tourism and Poverty Reduction. Channel View Books, Clevedon. 
14. Harrison, D. (2008). Pro-poor Tourism: a critique. Third World Quarterly, 29(5), 851-86.

15. Jamali, D. (2007). The Case for Strategic Corporate Social Responsibility in Developing Countries. Business and Society Review, 112(1), 1-27.

16. Khana T., Plepu K., Sinha J. (2005). Strategies that fir emerging markets. HBR, 83(6), 63-76.

17. Liu, A. \& Wall, G. (2006). Planning tourism employment: a developing country perspective. Tourism Management, 27(1), 159-170.

18. Mahato, S.S. (2013). Managing Tourism: An Observation in Developing Countries with Special Reference to Tanzania. The Oriental Anthropologist, 13(1), 121.

19. Md Sanaul Haque Mondal (2017). SWOT Analysis And Strategies To Develop Sustainable Tourism In Bangladesh. UTMS Journal of Economics, 8(2), 159-167.

20. Rivera, J. (2002). Assessing a Voluntary Environmental Initiative in the Developing World: The Costa Rican Certification for Sustainable Tourism. Policy Sciences, 35(4), 333-360.

21. Rivera, M.A. (2017). The synergies between human development, economic growth, and tourism within a developing country: An empirical model for Ecuador. Journal of Destination Marketing \& Management, 6(3), 221-232.

22. Schmude, J., Zavareh, S., Schwaiger, K.M. \& Karl, M. (2018). Micro-level assessment of regional and local disaster impacts in tourist destinations. Tourism Geographies, 20(2), 290-308.

23. Schubert, S.F., Brida, J.G. \& Risso, W.A. (2011). The impacts of international tourism demand on economic growth of small economies dependent on tourism. Tourism Management, 32(2), 377-385.

24. Whitelaw, P.A., King, B.E.M. \& Tolkach, D. (2014). Protected areas, conservation and tourism - financing the sustainable dream. Journal of Sustainable Tourism, 22(4), 584-603.

25. Yfantidou, G. \& Matarazzo, M. (2017). The Future of Sustainable Tourism in Developing Countries. Sustainable Development, 25(6), 459-466. 